\title{
Sajátmárkás élelmiszerek - lehetőség vagy veszély a magyarországi élelmiszer-feldolgozók számára?
}

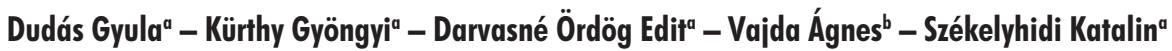 \\ - Radóczné Kocsis Teréz ${ }^{a}$ - Takács Eszter ${ }^{a}$ \\ aNAIK - Agrárgazdasági Kutatóintézet, bÁllatorvostudományi Egyetem
}

\begin{abstract}
A TANULMÁNY CÉLJA
Európában és Magyarországon is figyelemre méltó részesedést ér el a sajátmárkás termékek részaránya az élelmiszertermékek piacán, továbbá kiemelt fontossággal bírnak a kiskereskedelmi láncok számára, mivel jelentősen hozzájárulnak az adott lánc iránti fogyasztói elköteleződés kialakulásához. A koncentrált kiskereskedelemmel szemben a beszállítók többsége gyenge érdekérvényesítő képességgel bír, és ennek része a sajátmárkás termékek jelenléte is. Kutatásunk ezért arra irányult, hogy feltárjuk a magyarországi élelmiszer-feldolgozók körében a sajátmárkás termékek gyártásával kapcsolatos tapasztalatokat, a gyártás mögötti okokat és motivációs tényezőket.
\end{abstract}

\section{ALKALMAZOTT MÓDSZERTAN}

Kutatásunk szakirodalmi áttekintés mellett primer kérdőíves felmérésre épült. A kérdőíves felmérés 2018ban készült. A kérdőívet mintegy négyezer élelmiszeripari cégnek küldtük ki. Válasz 157 cégtől érkezett, amelyek közül 68 gyártott sajátmárkás termékeket kereskedelmi láncok számára.

\section{LEGFONTOSABB EREDMÉNYEK \\ A sajátmárkás termékek a beszállítók gyártói márkáinak közvetlen versenytársai, ezért megkerülhetetlen tényezőnek számítanak a magyarországi élelmiszer-ellátási láncban is. A magyarországi élelmiszer-feldol- gozók a sajátmárkás termék-előállítás előnyeként leggyakrabban a kapacitáskihasználást, a piaci részesedés növelését, az állandó, nagy mennyiségben való termelést és a kiszámítható árbevételt említették. A legy- gyakoribb hátrányok közé az alacsony jövedelmezöséget, a kereskedelemnek való kiszolgáltatottságot és a termék helyettesíthetőségét sorolták. A sajátmárkás terméket nem gyártó élelmiszer-feldolgozók körében a sajátmárkás termék-előállítástól való távolmaradást az elegendő termelői kapacitás hiánya mellett a gyártási lehetőség felmerülésének hiánya okozta, továbbá fontos szempont volt a gyártói márka védelme is.}

\section{GYAKORLATI JAVASLATOK}

A sajátmárkás termékek gyártásának hatása a feldolgozóipar helyzetére nem ítélhető meg egyértelműen sem pozitív, sem negatív jelenségként, mindig az adott cég egyéni helyzetétől és stratégiájától függ, milyen előnyeit aknázza ki ennek és cserébe milyen hátrányokat visel el. A cégek részéről jellemzően tudatos döntés, hogy milyen mértékben - árbevételük mekkora arányáig - köteleződnek el a sajátmárkák gyártása felé, ezért a külső beavatkozás lehetőségei korlátozottak, leginkább a beszállítók és kiskereskedelem közötti etikus kapcsolat kialakításának támogatása tủnik müködőképesnek.

Kulcsszavak: sajátmárkás termék, élelmiszeripar, kereskedelmi lánc, alkuerő, motiváció

DOI: https://doi.org/10.15170/MM.2019.53.04.03 


\section{BEVEZETÉS}

Sajátmárkás terméknek nevezzük azokat a termékeket, amelyeket egy kereskedelmi lánc a saját neve vagy egy általa használt név alatt kizárólagosan forgalmaz. A nemzetközi és a hazai szakirodalom a sajátmárka mellett a kereskedelmi márka megnevezést is gyakran használja, ezért a továbbiakban a sajátmárka és a kereskedelmi márka megnevezést szinonimaként használjuk.

A sajátmárkás termékek piaci részaránya nélkülözhetetlen információ az élelmiszer-feldolgozó vállalkozásoknak, mivel ennek tükrében határozható meg, hogy a sajátmárkás termékek térhódítása mellett mekkora piaci szegmens marad a gyártói márkák számára, illetve érdemes-e, szükséges-e bekapcsolódni a sajátmárkás termékek gyártásába.

A nemzetközi kitekintés során a Nielsen Piackutató Vállalat által publikált adatokra támaszkodtunk, amelyeket Magyarország esetében kiegészítettünk a GfK Hungária Piackutató Intézet által végzett felmérések eredményeivel.

\section{Sajátmárkás termékek jelenléte nemzet- közi viszonylatban}

A Nielsen (2018a) több mint hatvan országra kiterjedő felmérése alapján a sajátmárkás termékek piaci részesedése a napi fogyasztási cikkek (Fast Moving Consumer Goods, FMCG) piacán - érték alapján - átlagosan 16,7 százalékot tett ki világszinten 2016-ban, ugyanakkor az egyes térségek között jelentős eltérések mutatkoztak. A vizsgált térségek közül Európában a legmagasabb (31,4 százalék) e termékszegmens piaci részaránya, majd Észak-Amerika (17,7 százalék), Latin-Amerika (8,3 százalék), valamint Ázsia és Óceánia térsége következett (4,2 százalék).

A Nielsen (2018a) kilenc nyugat-európai országra vonatkozóan - érték alapján - közzétett adatai alapján Európában az első három helyen Spanyolország (42 százalék), az Egyesült Királyság (41 százalék) és Németország (36 százalék) állt 2016-ban, majd Belgium, Ausztria és Portugália következett sorrendben 32-32, illetve 30 százalékos piaci részaránnyal. A felmérésben bemutatásra kerültek továbbá még Hollandia (27 százalék), Franciaország (26 százalék) és Olaszország
(19 százalék) adatai is. Franciaországon és Portugálián kívül stagnálás vagy enyhe növekedés figyelhető meg a vizsgált országokban 2013 és 2016 között. A Nielsen 2018-as jelentése nem közöl Svájcra vonatkozóan adatokat, de egy korábbi kutatásuk szerint a sajátmárkás termékek 45 százalékos piaci részarányával Svájc nemcsak Európában, hanem a világon is első helyen állt 2013-ban (Nielsen 2014).

\section{Sajátmárkás termékek jelenléte Magyarországon}

A GfK Hungária (2015a, 2015b, 2016, 2017, 2018) adatai alapján ${ }^{1}$ Magyarországon a sajátmárkás termékek részesedése - értékben - a napi fogyasztási cikkek piacán 2000 és 2010 között folyamatosan emelkedve 25 százalékos részesedést ért el 2010re, majd némi visszaesés után az azt követő négy év mindegyikében 23 százalékos részarányt képviselt, ami 2015-töl évi egy százalékponttal újra növekedett, így 2017-ben 26 százalékot tett ki. Az utóbbi évek emelkedéséhez hozzájárult a diszkontláncok piaci részesedésének folyamatos bövülése is, amelyek forgalmának közel kétharmada a sajátmárkás termékek értékesítéséből származik (1. ábra).

\footnotetext{
1 „A GfK Hungária 2000 óta követi nyomon a napi fogyasztási cikkek piacán az egyes márkatípusok részesedésének és a vonatkozó vásárlói szokásoknak az alakulását. A GfK ConsumerScan adatai alapján évente összegzi a föbb változásokat, alkalmanként 2 ezer háztartás bevonásával közel 150 mért FMCG kategóriára vonatkozóan. A háztartások összetétele országosan reprezentatív a régió, településnagyság, háztartásnagyság, háziasszony életkora, háztartásfő foglalkozása és gyermek jelenléte szerint” (GfK 2015b).
} 


\section{1. ábra: A kereskedelmi márkák és a diszkontláncok értékbeli részesedése a napi fogyasztási cikkek piacán, 2010-2017}

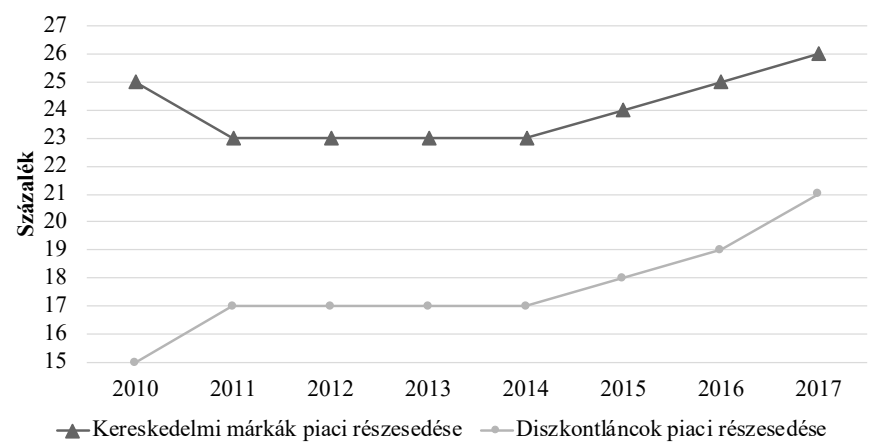

Megjegyzés: A SPAR 2008-ban magába olvasztotta a Plusz diszkontláncot. A Plusz diszkontok szupermarketekké való átpozicionálása is szerepet játszott abban, hogy a diszkontláncok piaci részesedése 15 százalékra csökkent 2010-ben a 2008-ban mért 18 százalékhoz képest.

Forrás: saját szerkesztés a GfK Hungária $(2015 a, 2015 b, 2016,2017,2018)$ adatai alapján

A Nielsen adatai ${ }^{2}$ alapján a sajátmárkás élelmiszerek értékben mért piaci részesedése 2010 és 2017 között 23 százalékról 29 százalékra emelkedett Magyarországon, ami közel 500 milliárd forint értékủ sajátmárkás élelmiszer-forgalmat takart 2017-ben. Bár a Nielsen és a GfK Hungária eltérő módszertan alapján gyüjti az adatokat, de a kapott eredmények mindkét piackutató esetében azonos tendenciát jeleznek, vagyis általánosságban növekszik e termékszegmens fogyasztói elfogadottsága (2. ábra).

\section{2. ábra: A kereskedelmi márkák értékbeli részesedése} a napi fogyasztási cikkek és az élelmiszertermékek piacán, 2010-2017

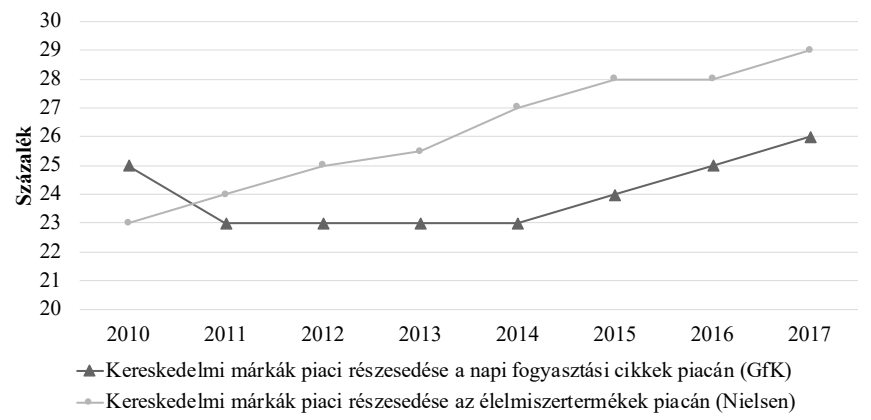

Megjegyzés: A 2013. évi Nielsen-adat 2013. év elsö fél évének adata.

Forrás: saját szerkesztés a GfK Hungária (2015a, 2015b, 2016, 2017, 2018) adatai, valamint a Menedzsment Fórum (2011), a BrandTrend (2013a, 2013b) és a Nielsen (2016, 2017, 2018b) publikációkban szereplö Nielsen-adatok alapján

2 A Nielsen a kereskedelmi láncokból származó elektronikus és a hagyományos kiskereskedelmi egységek adatai alapján 90 élelmiszer-kategóriában méri a sajátmárkás termékek forgalmi adatait és piaci részesedését. 


\section{A SAJÁTMÁRKÁS TERMÉKEK BESZÁLLÍTÓKRA GYAKOROLT HATÁSA}

A globális élelmiszerláncban a gyártói márkák és a kiskereskedők sajátmárkái közötti határok egyre inkább elhalványulnak. A 2010-es évek közepére a kiskereskedők a sajátmárkáikon keresztül a fogyasztók megnyerésére alkalmas, versenyképes termékeket forgalmaznak (Olbrich et al. 2016). A sajátmárkás termékek a beszállítók gyártói márkáinak közvetlen versenytársaivá váltak. A kiskereskedők sajátmárkái hatással vannak mind az élelmiszer-ellátási láncon belüli versenyre, mind pedig a fogyasztók számára elérhető élelmiszerek termékválasztékára. A sajátmárkás termékek egyrészt növelik az elérhető termékek körét, ezáltal növelik az árversenyt, másrészt megváltoztatják a kiskereskedök és beszállítóik közötti kapcsolatot (Bunte et al. 2011).

Kezdetben a sajátmárkás termékek a minimális vásárlói igényeket elégítették ki. Ezt a minőségük és a csomagolásuk is tükrözte. A fogyasztói igényekre reagálva a kiskereskedők folyamatosan javították a sajátmárkás termékek minőségét, csomagolását és marketingjét, így azok már elérik, sőt gyakran meg is haladják egyes gyártói márkák színvonalát az elöbbi jellemzőkben. Ezek a sajátmárkás termékek már komolyabb kihívást jelentenek a gyártók számára. A sajátmárkák segítségével megkülönböztethető boltimázst lehetett felépíteni, jó minőségü és kizárólagos forgalmazású sajátmárkákkal pedig bolthűség volt kialakítható, amely növelte az üzletek forgalmát (Richardson et al. 1996, Sethuraman \& Cole 1997, Sayman et al. 2002, Pepe et al. 2011). A sajátmárkák bevezetése a kiskereskedőket egyre erősebb alkupozícióba juttatta a beszállítókkal szemben, mivel csökkent a függőségük a gyártói márkáktól (Wijmans 2010).

Hultman és szerzőtársai (2008), valamint Olson (2012) arra hívták fel a gyártói márkát előállító vállalatok figyelmét, hogy csak akkor fogjanak bele kiskereskedelmi sajátmárka elöállításába, ha biztosítani tudják, hogy erről a vásárló nem szerez tudomást, vagy ha mégis, akkor tisztán érzékelhető legyen a gyártói márkájuk minőségi előnye. A közös gyártásról való információ ugyanis a prémium kereskedelmi márka iránti attitűdöt javítja, a gyártói márkáét rontja. Ez is oka lehet annak, hogy a gyártók körében a sajátmárkás termékek címkéjén a gyártói név feltüntetésének megítélése meglehetősen ellentmondásos/különböző.

A nagy élelmiszeripari vállalatok mellett a kkv-k is fontos szerepet játszanak a kiskereske- delmi láncok sajátmárka-kínálatában. Számukra a sajátmárka gyártása szempontjából különösen elönyös lehet, hogy a gyártó vállalkozásoknak nem kell viselniük a márkafejlesztéssel kapcsolatos költségeket. A sajátmárkák gyártása révén több ezer olyan kkv, amely egyébként nem tudna versenyezni a multinacionális gyártókkal, lép be a nemzetközi piacra (Kate \& Wal 2017).

A modern kiskereskedelemben a kiskereskedők és beszállítóik kapcsolatát a folyamatos együttmüködés, koordináció és kommunikáció adja. A hatékonyságnövelés, az ellátási lánc zavartalan müködése, a folyamatosan változó fogyasztói kereslethez való igazodás miatt a kiskereskedők és a beszállítók egyre szorosabban együttmüködnek (Delbergh 2015).

Magyarországon kevésbé figyelhető meg az a kooperációs folyamat a termékfejlesztésre vonatkozóan a kereskedelem és a gyártók között, ami fejlettebb országokban létezik, továbbá a beszállítók kiszolgáltatottságát és jövedelmi helyzetét rontotta a sajátmárkák terjedése (Kürthy és tsai 2011).

A sajátmárkás termékek térnyerésének beszállítókra gyakorolt hatásait vizsgálva Juhász és szerzőtársai (2010) a magyar élelmiszerfeldolgozók között végzett kérdöíves felmérésük alapján megállapították, hogy a sajátmárka gyártása „kétélű fegyver”. A gyártói kapacitások kihasználásának növelése, az állandó, nagy mennyiségủ beszállítási lehetőség, így az egységköltségek csökkenése, az alacsonyabb ár és a növekvő forgalom összefüggésében lehet a beszállítókra gyakorolt hatást pozitívumként említeni, ugyanakkor hátrány a beszállítók számára, hogy a feldolgozóipari vállalatok még inkább függő helyzetbe kerültek a kiskereskedelemtől a sajátmárkás termékek által, és megfigyelhető a kereskedelmi erőfölény alkalmazása is e termékekkel kapcsolatban, ami a beszállítók szemszögéből az alacsony jövedelmezőség mellett a márkakannibalizáció és a beszállítói lecserélhetőség veszélyét növeli.

\section{A KUTATÁS MÓDSZERTANA}

Kérdőíves felmérésünk a sajátmárkás termékek gyártása mögötti okokat és motivációs tényezőket vizsgálta 2018-ban. A kérdőív kidolgozásához alapul szolgált Juhász és szerzőtársai (2010) kutatása. Kutatásunk során az alábbi kérdésekre kerestük a választ:

- Milyen előnyeit érzékelik, illetve hátrányait szenvedik el az élelmiszer-feldolgozók a sajátmárkás termék-elöállításnak? 
- Ha egy élelmiszer-feldolgozó nem gyárt sajátmárkás terméket, akkor mi annak az oka?

Hipotézisünk az volt, hogy Juhász és szerzőtársai (2010) által megfogalmazott előnyök és hátrányok továbbra is fennállnak, de azt vártuk, hogy a sajátmárkás termékek terjedése miatt ezek markánsabban fogalmazódnak meg, esetleg elmozdul a cégek megítélése a pozitívumok felé.

A kérdőívet minden olyan, kettős könyvvitelt vezető, TEÁOR szám alapján élelmiszeriparba sorolt cégnek kiküldtük Magyarországon, amely interneten fellelhető e-mail címmel rendelkezett. A megkeresett mintegy négyezer élelmiszer-feldolgozó közül 157-től érkezett válasz, ebből 68 olyan cégtöl, amely gyárt sajátmárkás termékeket kereskedelmi láncok számára. A kérdőív sajátmárkákra vonatkozó részét e gyártók közül néhányan azonban csak részben töltötték ki, ezért a válaszadók számát külön jelöljük, ahol az nem éri el a 68-at.
Emellett kérdőívünk lehetőséget biztosított arra is, hogy feltárjuk azokat az okokat, amelyek 89 vállalkozásnál a sajátmárkás termékgyártástól való távolmaradást eredményezték.

A mintában szereplő sajátmárkás termékeket előállító gyártók a takarmányipar kivételével valamennyi alágazatot képviselték. A mintában szereplő sajátmárkás gyártók $(\mathrm{N}=68)$ közel ötöde a pékáru és tésztafélék gyártása, 17,6-17,6 százalékuk a húsfeldolgozás és -tartósítás, húskészítmények gyártása, valamint az italgyártás alágazatban érdekelt vállalkozás volt, de közel hasonló arányban (16,2 százalék) vettek részt felmérésünkben a gyümölcs- és zöldségfeldolgozó vállalkozások is. Méretüket tekintve a mintában szereplő sajátmárkás gyártók $(\mathrm{N}=68)$ fele 50 főnél kisebb létszámmal müködő mikro- és kisvállalkozás, 25,0-25,0 százalékuk pedig közepes és nagy méretü cég volt. (1. táblázat).

\section{1. táblázat: A sajátmárkás terméket gyártó cégek alágazat és méret szerinti megoszlása a mintában $(\mathrm{N}=68)$}

\begin{tabular}{|c|c|c|c|c|c|c|}
\hline \multirow{2}{*}{ Alágazat } & \multirow{2}{*}{$\begin{array}{c}\text { Elemszám, } \\
\text { db }\end{array}$} & \multirow{2}{*}{$\begin{array}{c}\text { Megoszlás, } \\
\%\end{array}$} & \multicolumn{4}{|c|}{ Vállalati méret } \\
\hline & & & $\begin{array}{l}\text { Mikro, } \\
\text { db }\end{array}$ & $\begin{array}{c}\text { Kis, } \\
\text { db }\end{array}$ & $\begin{array}{c}\text { Közép, } \\
\text { db }\end{array}$ & $\begin{array}{l}\text { Nagy, } \\
\text { db }\end{array}$ \\
\hline Pékáru, tésztafélék gyártása & 13 & 19,1 & 2 & 3 & 5 & 3 \\
\hline $\begin{array}{l}\text { Húsfeldolgozás, -tartósítás, } \\
\text { húskészítmények gyártása }\end{array}$ & 12 & 17,6 & 1 & 1 & 3 & 7 \\
\hline Italgyártás & 12 & 17,6 & 9 & 2 & 1 & 0 \\
\hline $\begin{array}{l}\text { Gyümölcs-, zöldségfeldolgozás, } \\
\text {-tartósítás }\end{array}$ & 11 & 16,2 & 3 & 2 & 3 & 3 \\
\hline Tejfeldolgozás & 10 & 14,7 & 2 & 2 & 2 & 4 \\
\hline Egyéb élelmiszer gyártása & 7 & 10,3 & 3 & 1 & 3 & 0 \\
\hline Malomipari termék, keményítő gyártása & 2 & 2,9 & 2 & 0 & 0 & 0 \\
\hline Növényi, állati olaj gyártása & 1 & 1,5 & 0 & 1 & 0 & 0 \\
\hline Összesen & 68 & 100,0 & 22 & 12 & 17 & 17 \\
\hline
\end{tabular}

Forrás: saját számitás

A válaszadók $(\mathrm{N}=66)$ belföldi nettó értékesítésében a sajátmárkákból származó bevétel aránya a vállalkozások mintegy harmadánál 1-20 százalék, negyedüknél pedig 21-40 százalék között mozgott. A cégek ötödénél az árbevétel 81-100 százaléka e termékek értékesítéséből származik. Mintánkban azok a cégek, amelyek belföldi nettó értékesítésének jelentős hányadát a sajátmárkás termékek értékesítése adja, jellemzően mikrovállalkozások voltak (2. táblázat). 
2. táblázat: A sajátmárkás termékek aránya a belföldi nettó értékesítés árbevételéből, vállalati méret szerinti megoszlás $(\mathrm{N}=66)$

\begin{tabular}{lcccccc}
\hline Kategóriák & $\begin{array}{c}\text { Elemszám, } \\
\mathbf{d b}\end{array}$ & $\begin{array}{c}\text { Megoszlás, } \\
\mathbf{\%}\end{array}$ & $\begin{array}{c}\text { Mikro, } \\
\mathbf{d b}\end{array}$ & $\begin{array}{c}\text { Kis, } \\
\mathbf{d b}\end{array}$ & $\begin{array}{c}\text { Közép, } \\
\mathbf{d b}\end{array}$ & $\begin{array}{c}\text { Nagy, } \\
\mathbf{d b}\end{array}$ \\
\hline $1-20 \%$ & 21 & 31,8 & 7 & 3 & 5 & 6 \\
\hline $21-40 \%$ & 16 & 24,2 & 2 & 4 & 4 & 6 \\
\hline $41-60 \%$ & 12 & 18,2 & 1 & 3 & 4 & 4 \\
\hline $61-80 \%$ & 4 & 6,0 & 1 & 0 & 3 & 0 \\
\hline $81-99 \%$ & 6 & 9,0 & 5 & 1 & 0 & 0 \\
\hline $100 \%$ & 7 & 10,6 & 5 & 1 & 1 & 0 \\
\hline Összesen & 66 & 100,0 & 21 & 12 & 17 & 16 \\
\hline
\end{tabular}

Forrás: saját számitás

A 2016. évi árbevétel-adatok alapján a mintában található cégek sajátmárkás termékértékesítésből származó becsült nettó árbevétele megközelítette a 95 milliárd forintot. A sajátmárkás termékek esetében az alapsokaság, azaz a sajátmárkás terméket gyártó cégek számának és összetételének megállapítása nem lehetséges/nehézségekbe ütközik, mivel erre vonatkozóan nincs elérhető adatbázis. Az általunk vett minta nem tekinthető reprezentatívnak, így nem vonhatunk le biztos következtetéseket az alapsokaságra vonatkozóan. Ennek fényében a matematikai statisztikai elemzés elvégzését elvetettük. Az eredmények iránymutató jellegủek.

\section{KUTATÁSI EREDMÉNYEK}

\section{Sajátmárkák gyártásának előnyei a gyártók számára}

Egyidejüleg számos tényező ösztönözte a válaszadókat $(\mathrm{N}=68)$ a sajátmárkás termékek gyártására. Elönyként leggyakrabban (82,4 százalék) a kapacitáskihasználást, ezt követően pedig a piaci részesedés növelését, az állandó, nagy mennyiségben való termelést és a kiszámítható árbevételt említették. A kapott átlagértékek alapján a válaszadók a legfontosabb pozitívumnak ezek közül a kapacitáskihasználást $(4,23)$ és a piaci részesedés növelését $(3,90)$ tekintették. Közepesnél jelentösebb előnynek vélték továbbá az állandó, nagy mennyiségben való termelést $(3,75)$ is. A sajátmárkás termékgyártás előnyei közül legkevésbé jelentösnek $(2,91$ és 2,94$)$ a marketingköltség hiánya és a kevesebb hátsó kondíció bizonyult számukra (3. táblázat). 


\section{3. táblázat: A sajátmárkás termék-elóállítás előnyei ( $\mathrm{N}=68)$}

\begin{tabular}{lcccc}
\hline Kategóriák & $\begin{array}{c}\text { Említések } \\
\text { száma, db }\end{array}$ & Átlag & $\begin{array}{c}\text { Említések } \\
\text { gyakorisága, \% }\end{array}$ & $\begin{array}{c}\text { 9-es (nem releváns) } \\
\text { válaszok száma, db }\end{array}$ \\
\hline Kapacitáskihasználás & 56,0 & 4,23 & 82,4 & 5 \\
\hline $\begin{array}{l}\text { Piaci részesedés } \\
\text { megtartása/növelése }\end{array}$ & 51,0 & 3,90 & 75,0 & 3 \\
\hline Állandó, nagy mennyiség & 51,0 & 3,75 & 75,0 & 6 \\
\hline Kiszámítható árbevétel & 51,0 & 3,69 & 75,0 & 6 \\
\hline Állandó költségek viselöje & 48,0 & 3,73 & 70,6 & 6 \\
\hline Logisztikai előny & 47,0 & 3,23 & 69,1 & 13 \\
\hline Alacsonyabb marketingköltség & 38,0 & 3,13 & 55,9 & 12 \\
\hline Kevesebb hátsó kondíció & 36,0 & 2,94 & 52,9 & 15 \\
\hline Nincs marketingköltség & 33,0 & 2,91 & 48,5 & \\
\hline
\end{tabular}

Megjegyzés: 1-es válasz =egyáltalán nem jelentös, 5-ös válasz=nagyon jelentős, 9-es válasz=nem releváns.

Forrás: saját számitás

A kapacitáskihasználást a válaszadók 82,4 százaléka a pozitívumok közé sorolta és 58,9 százalékuk ezt teljes mértékben érzékeli. Azok aránya, akik a kapacitáskihasználást szintén említették, de előnyét csak kisebb mértékben tapasztalták, összesen 23,2 százalék volt. A piaci részesedés növelését, az állandó, nagy mennyiségben való termelést és a kiszámítható árbevételt a válaszadók összesen
75,0-75,0 százaléka emelte ki, előbbi kettőt 39,2 és 31,4 százalékuk, utóbbit pedig 33,3 százalékuk érezte saját cégük esetén nagyon jelentősnek (3. ábra). A válaszadók legkevésbé a marketingköltség hiányát és a kevesebb hátsó kondíciót érezték előnynek és közülük is csak minden ötödik-hetedik válaszadó vélte azokat saját vállalkozása esetén nagyon jelentősnek.

\section{3. ábra: A sajátmárkás termék-előállítás előnyeire adott osztályzatok megoszlása, százalék $(\mathrm{N}=68)$}

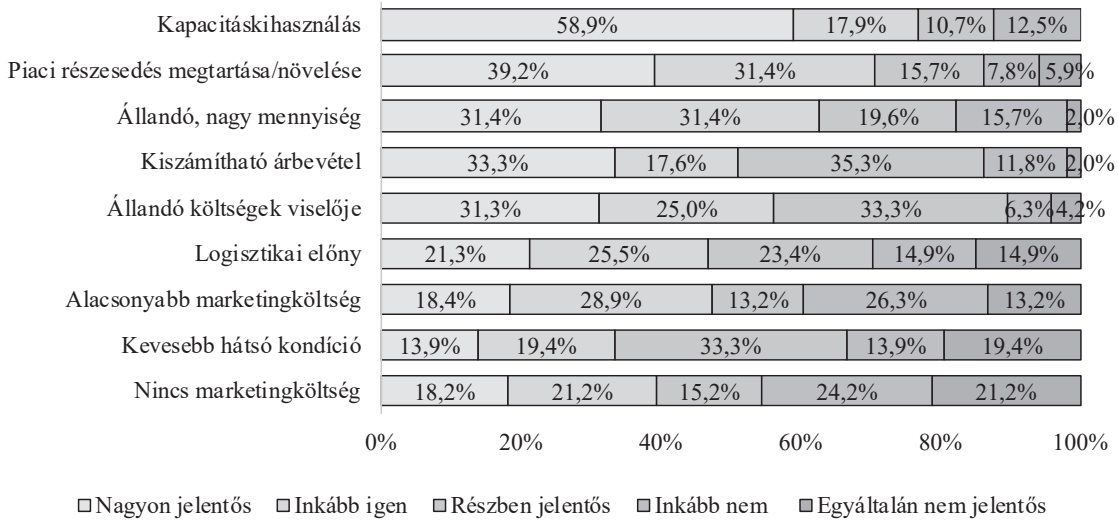

Forrás: saját számitás 
Válaszadóink a kérdőívben felsoroltakon kívül egyéb előnyeit is látják a sajátmárkás termékek gyártásának. Ketten említették, hogy ez az üzleti kapcsolat segíti az áruházak polcain való megjelenésüket. Szintén két válaszadó vélte úgy, hogy a sajátmárkás termékek előállításának köszönhetően kedvezőbb partneri kapcsolat alakítható ki. Egy fö azt emelte ki, hogy a sajátmárkás termékek egyedisége miatt nem kell konkurenciával számolni. Egy másik válaszadó szerint e termékek gyártása növeli a cég elismertségét. Egy válaszadó az innovatív termékek gyártásának lehetőségét említette.

\section{Sajátmárkák gyártásának hátrányai a gyártók számára}

A válaszadók $(\mathrm{N}=68)$ többsége elsősorban az alacsony jövedelmezőséget (72,1 százalék) és a kereskedelemnek való kiszolgáltatottságot (szintén 72,1 százalék) említette, de ugyanekkora arányban voltak azok is, akik a termék helyettesíthetőségét sorolták a legfőbb hátrányok közé. A sajátmárkás gyártás további, viszonylag gyakran $(67,6$ százalék) említett hátulütőjének a beszállítói lecserélhetőség bizonyult a cégektől kapott válaszok alapján. A saját cégen belüli innováció háttérbe szorulását csak 55,9 százalékuk érezte vállalkozását tekintve jellemző állításnak (4. táblázat).

A válaszok értékelésénél kapott átlagértéket összehasonlítva az a következtetés vonható le, hogy az alacsony jövedelmezőség $(3,90)$ általánosan véve az egyik legkomolyabb probléma a sajátmárkás előállítók számára. Ezt a kereskedelemnek való kiszolgáltatottság és a beszállítók lecserélhetösége követi 3,69, illetve 3,65 átlagponttal. A termék helyettesíthetősége szintén azon kedvezőtlen tényezök közé tartozott, amit közepesnél súlyosabb $(3,47)$ problémának véltek. A negatív árspirált, amely a gyártói márkára is hatással lehet hoszszú távon, a megkérdezettek előbbiekhez képest kevésbé érezhető negatívumként $(3,40)$ ítélték meg, és a márkakannibalizáció jelentette hátrányokról is hasonló módon vélekedtek (4. táblázat).

\section{4. táblázat: A sajátmárkás termék-előállítás hátrányai $(\mathrm{N}=68)$}

\begin{tabular}{lcccc}
\hline Kategóriák & $\begin{array}{c}\text { Említések } \\
\text { száma, db }\end{array}$ & Átlag & $\begin{array}{c}\text { Említések } \\
\text { gyakorisága, \% }\end{array}$ & $\begin{array}{c}\text { 9-es (nem releváns) } \\
\text { válaszok száma, db }\end{array}$ \\
\hline Alacsony jövedelmezőség & 49 & 3,90 & 72,1 & 6 \\
\hline $\begin{array}{l}\text { Kiszolgáltatottság a kereske- } \\
\text { delemnek }\end{array}$ & 49 & 3,69 & 72,1 & 7 \\
\hline $\begin{array}{l}\text { Termék helyettesíthetősége } \\
\text { Beszállítói lecserélhetőség }\end{array}$ & 49 & 3,47 & 72,1 & 4 \\
\hline $\begin{array}{l}\text { Negatív árspirál (a gyártói } \\
\text { márka árára is hatással lehet } \\
\text { hosszabb távon) }\end{array}$ & 43 & 3,65 & 67,6 & 6 \\
\hline $\begin{array}{l}\text { Márkakannibalizáció } \\
\text { Saját cégen belüli innováció } \\
\text { háttérbe kerül }\end{array}$ & 38 & 3,40 & 63,2 & 8 \\
\hline
\end{tabular}

Megjegyzés: 1-es válasz =egyáltalán nem jelentös, 5-ös válasz=nagyon jelentös, 9-es válasz=nem releváns. Forrás: saját számítás

Az alacsony jövedelmezőséget említő válaszadók összesen 49,0 százaléka állította, hogy nagyon jelentős problémát okoz számukra a mérsékelt profitabilitás. Azoknak az aránya, akik a kereskedelemnek való kiszolgáltatottságot vélték igen komoly hátránynak saját vállalkozásuk esetén,
36,7 százalék volt. Ehhez hasonló arányban érezték jelentős negatívumnak a beszállítói lecserélhetőséget is (4. ábra). 


\section{4. ábra: A sajátmárkás termék-előállítás hátrányaira adott osztályzatok megoszlása, százalék $(\mathrm{N}=68)$}

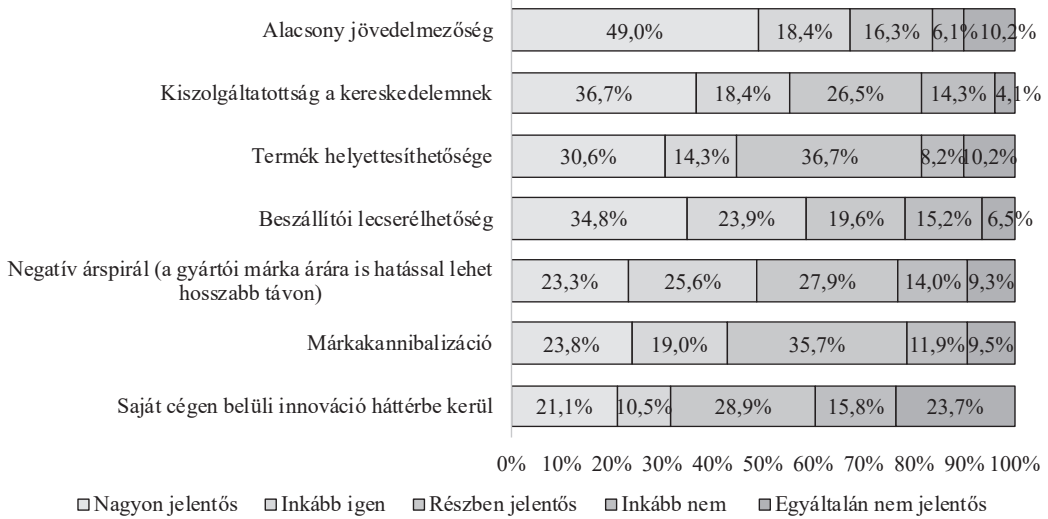

Forrás: saját számitás

A sajátmárkás termékgyártás előnyeinek és hátrányainak vizsgálata során Juhász és szerzőtársai (2010), valamint a jelen kutatás eredményei alapján is a legnagyobb pozitívumot az élelmiszer-feldolgozók számára a kapacitáskihasználás növelése és az állandó, nagy mennyiségben való termelés jelentette. Lényegi eltérés a két kutatás között, hogy a piaci részesedés megtartása/ növelése felzárkózott az állandó, nagy mennyiség és a kiszámítható árbevétel mellé az említések gyakoriságát tekintve. Ezt a megítélésbeli változást a sajátmárkás termékek piaci részarányának elmúlt években tapasztalt emelkedése magyarázza, ami egyre több gyártót ösztönöz/kényszerít arra, hogy bekapcsolódjon a sajátmárkás termék-elöállításba.

A leggyakrabban említett hátrány, vagyis az alacsony jövedelmezőség magas említésszámot kapott már 2010-ben is. Jelentős változás viszont, hogy a kereskedelemnek való kiszolgáltatottság és a termék helyettesíthetősége 2010-ben még a legkevésbé tapasztalt hátrányok közé tartoztak, addig e két tényező az alacsony jövedelmezőséggel együtt a három leggyakrabban jelölt hátránnyá vált. Szintén figyelemreméltó különbség, hogy a márkakannibalizáció 2018-ban a lista végén szerepelt. Ezzel hipotézisünket részben igazoltnak tekintjük.

A kereskedelem jelentős erőfölénye, valamint az ebből fakadó alkupozíció a tisztességtelen kereskedelmi gyakorlat alkalmazásának kockázatát is növelheti a kisebb sajátmárkás gyártókkal szemben (Európai Bizottság 2013). A negatív hatások viszont részben elkerülhetők, ha a gyártók saját márkáik építésébe is folyamatosan invesztálnak, márkatermékeiknek konkurenciát jelentő terméket lehetőleg nem állítanak elő, valamint kereskedelmi kapcsolataikat is kiterjesztik, partnereik számát bővítik (Hultman et al. 2008, Quelch \& Harding 1996).

\section{A sajátmárkás termeléstől való távol- maradás föbb okai}

Kutatásunk során igyekeztünk feltárni azokat az okokat, amelyek 89 vállalkozás esetén a sajátmárkás gyártásból való kimaradást eredményezték. Ezen vállalkozások 89 százaléka mikro- vagy kisvállalkozás volt, mindössze 11 százalékuk tartozott közepes vagy nagy vállalati méretbesorolás alá (5. ábra). 


\section{5. ábra: A sajátmárkás termék-előállítástól távol maradó}

vállalkozások méret szerinti megoszlása, százalék $(\mathrm{N}=89)$

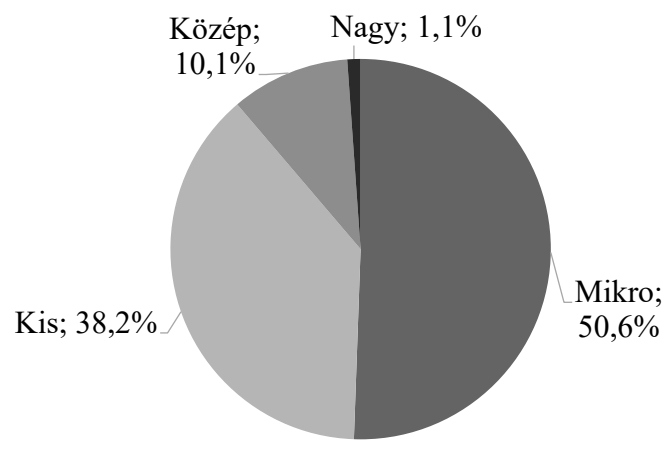

Forrás: saját számitás

A mikro- és kisvállalkozásoknak elsősorban az elegendő kapacitás, a lehetőség felmerülésének hiánya jelent akadályt, továbbá fontos szempont számukra a gyártói márka védelme is. Korábbi rossz tapasztalattal csak e vállalati kör rendelkezett, továbbá a vevői követelmények teljesítése is e cégek számára jelentett kihívást. A közép és nagyméretủ cégek csoportján belül a gyártói márka védelme és a vevőkkel szembeni kiszolgáltatottság félelme jelent meg, de kilencböl négy közepes méretü vállalkozásnál megjelent az elegendő termelési kapacitás hiánya is (5. táblázat).

\section{5. táblázat: A sajátmárkás termék-előállítástól való távolmaradás okai $(\mathrm{N}=89)$}

\begin{tabular}{lccccc}
\hline Kategóriák & $\begin{array}{c}\text { Elemszám, } \\
\mathbf{d b}\end{array}$ & $\begin{array}{c}\text { Mikro, } \\
\mathbf{d b}\end{array}$ & $\begin{array}{c}\text { Kis, } \\
\mathbf{d b}\end{array}$ & Közép, db & Nagy, db \\
\hline $\begin{array}{l}\text { Nincs elegendö termelési kapa- } \\
\text { citásom }\end{array}$ & 27 & 10 & 13 & 4 & 0 \\
\hline $\begin{array}{l}\text { Még sosem merült fel ez a } \\
\text { lehetőség }\end{array}$ & 18 & 10 & 7 & 1 & 0 \\
\hline Védem a saját gyártói márkámat & 17 & 7 & 6 & 3 & 1 \\
\hline $\begin{array}{l}\text { Nem akarok kiszolgáltatott lenni } \\
\text { a vevőnek }\end{array}$ & 10 & 3 & 4 & 2 & 1 \\
\hline $\begin{array}{l}\text { Korábbi saját rossz tapasztalat } \\
\text { miatt }\end{array}$ & 9 & 7 & 2 & 0 & 0 \\
\hline $\begin{array}{l}\text { Nem tudok megfelelni a vevöi } \\
\text { követelményeknek }\end{array}$ & 6 & 5 & 1 & 0 & 0 \\
\hline
\end{tabular}

Forrás: saját számitás 


\section{ÖSSZEGZÉS}

A sajátmárkás termékek fogyasztói megítélése mind nemzetközi szinten, mind Magyarországon folyamatosan javul, ami egyik fó hajtóereje e termékek piaci térnyerésének. A fogyasztói bizalom növelése érdekében a kiskereskedelmi láncok az utóbbi évtizedekben nagymértékben javították a sajátmárkás termékek minőségét, bővítették választékát, megjelentek a sajátmárkák a prémium és a speciális fogyasztói igényeket kielégítő minőségi kategóriákban is. A sajátmárkás termékek a beszállítók gyártói márkáinak közvetlen versenytársai, így megkerülhetetlen tényezővé váltak az értékesítési láncban.

$\mathrm{Az}$ élelmiszer-feldolgozó cégek a sajátmárkás termék-elöállítás előnyeként leggyakrabban a kapacitáskihasználást, ezt követően pedig a piaci részesedés növelését, az állandó, nagy mennyiségben való termelést és a kiszámítható árbevételt említették. A gyártók piaci jelenlétének növelése, illetve megtartása e termékszegmens előállításába való bekapcsolódás nélkül többnyire már nem valósítható meg.

A gyártók az alacsony jövedelmezőséget, a kereskedelemnek való kiszolgáltatottságot és a termék helyettesíthetőségét sorolták a legföbb hátrányok közé. A sajátmárkás termékgyártás további, viszonylag gyakran említett hátulütőjének a beszállítói lecserélhetőség bizonyult.

A sajátmárkás terméket nem gyártó élelmiszer-feldolgozók körében a sajátmárkás termék-elöállítástól való távolmaradást az elegendő termelői kapacitás hiánya mellett a gyártási lehetőség felmerülésének hiánya okozta, továbbá fontos szempont volt a gyártói márka védelme is.

Összességében is az fogalmazható meg fö kutatási eredményként - amit mind a szakirodalmi adatok, mind a primer kutatási eredmények megerősítettek -, hogy a sajátmárkás termékek gyártásának hatása a feldolgozóipar helyzetére nem ítélhető meg egyértelmüen sem pozitív, sem negatív jelenségként, mindig az adott cég egyéni helyzetétől és stratégiájától függ, milyen előnyeit aknázza ki ennek és cserébe milyen hátrányokat visel el. Nagyon jellemző, hogy a cégek részéröl tudatos döntés, hogy milyen mértékben árbevételük mekkora arányáig - köteleződnek el a sajátmárkák gyártása felé.

\section{HIVATKOZÁSOK}

BrandTrend (2013a), „A kereskedelmi márkák részaránya", 2013. március 23. http:// brandtrend.hu/kutatas/2013/03/23/a-kereskedelmi-markak-reszaranya (letöltés: 2019.10.29.)

BrandTrend (2013b): „Javult a gyártói márkák piaci poziciója”, 2013. augusztus 28. http://brandtrend.hu/kutatas/2013/08/28/ javult-a-gyartoi-markak-piaci-pozicioja (letöltés: 2019.10.29.)

Bunte, F. H. J., Van Galen, M. A., De Winter M. A., Dobson, P., Bergès-Sennou, F., Monier-Dilhan, S., Juhász, A., Moro, D., Sckokai, P., Soregaroli, C., van der Meulen, B. M. J., Szajkowska, A. (2011), "The impact of private labels on the competitiveness of the European food supply chain", European Commisson Enterprise and Industry, Luxembourg: Publications Office of the European Union

Delbergh, C. (2015), The impact of modern retail on innovation and choice, Eurocommerce Comments on the DG Competition Study

Európai Bizottság (2013), Zöld Könyv. Az európai vállalatközi élelmiszer- és nemélelmiszerellátási lánc mentén alkalmazott tisztességtelen kereskedelmi gyakorlatokról. COM 201337 final, https://eur-lex.europa.eu/legal-content/ HU/TXT/PDF/?uri=CELEX:52013DC0037\&from=HU (letöltés: 2019.10.29.)

GfK Hungária (2015a), „Hosszú idő után a háztartások újra növelték napi fogyasztási cikk költéseiket”, Sajtóközlemény, 2015. április 14. https://www.gfk.com/fileadmin/user_upload/ dyna_content_import/2015-09-01_press releases/data/hu/Documents/20150414_GfK_ Kiskereskedelmi\%20trendek.pdf (letöltés: 2019.10.29.)

GfK Hungária (2015b), „A kereskedelmi márkák piaci részesedése az előző évi szinten maradt", Sajtóközlemény, 2015. június 30. https://www. gfk.com/fileadmin/user_upload/dyna_content_import/2015-09-01_press_releases/data/ hu/Documents/20150630_GfK_KerMarkaAnalizisek.pdf (letöltés: 2019.10.29.)

GfK Hungária (2016), „Tavaly minden negyedik forintot saját márkára költötték a fogyasztók", Sajtóközlemény, 2016. július 12. https://www. gfk.com/fileadmin/user_upload/country_one_ pager/HU/documents/20160712_GfK_Kereskedelmi_markak_i.pdf (letöltés: 2019.10 .29 .)

GfK Hungária (2017), „Rendületlenül nő a sajátmárkák piacrésze", Sajtóközlemény, 2017. 
június 14. https://www.gfk.com/fileadmin/ user_upload/country_one_pager/HU/documents/20170614_GfK_Kereskedelmi_ markak 2017.pdf (letöltés: 2019.10 .29 .)

GfK Hungária (2018), „2018-ban további mérsékelt növekedés várható a kiskereskedelemben", Sajtóközlemény, 2018. április 11. https://www. gfk.com/fileadmin/user_upload/country_one_ pager/HU/documents/20180411_GfK_Kiskereskedelem_teljesitmenye_2017ben.pdf (letöltés: 2019.10.29.)

Hultman, M., Opoku, R. A., Salehi-Sangari, E., Oghazi, P., Bui, Q. T. (2008), "Private label competition: The perspective of Swedish branded goods manufacturers", Management Research News, 31 2, 125-41 DOI: 10.1108/01409170810846849

Juhász A., Jankuné Kürthy Gy., Kőnig G., Stauder M., Tunyoginé Nechay V. (2010), A kereskedelmi márkás termékek gyártásának hatása az élelmiszer-kiskereskedelemre és beszállitóira, Budapest: Agrárgazdasági Kutató Intézet, Agrárgazdasági Könyvek

Kate, G., Wal, S. (2017), Eyes on the price. International supermarket buying groups in Europe, SOMO Stichting Onderzoek Multinationale Ondernemingen Paper, Centre for Research on Multinational Corporations

Kürthy Gy., Juhász A., Stauder M., Tunyoginé Nechay V. (2011), „A kereskedelmi márkák hatása az élelmiszer-termékpályán", Gazdálkodás, 55 3, 285-95

Menedzsment Fórum (2011), „Hóditanak a sajátmárkás termékek", 2011. március 8. https:// $\mathrm{mfor}$.hu/cikkek/vallalatok/Hoditanak_a_sajatmarkas_termekek.html

Nielsen (2014), "The state of private label around the world", https://www.nielsen.com/dz/en/ insights/report/2014/the-state-of-private-labelaround-the-world/ (letöltés: 2019.10.29.)

Nielsen (2016), „Közel 500 milliárd forint a sajátmárkás termékek forgalma”, 2016. március 7. https://www.nielsen.com/hu/hu/ press-room/2016/turnover-of-private-labels-nearly-500-billion-forints.html (letöltés: 2019.10.29.)

Nielsen (2017), „Megállt a kereskedelmi márkák térnyerése”, 2017. július 3. https://www nielsen.com/hu/hu/insights/article/2017/slower-penetration-of-private-labels/

Nielsen (2018a), "The rise and rise again private label", https:/www.nielsen.com/eu/en/insights/ report/2018/the-rise-and-rise-again-of-privatelabel/\# (letöltés: 2019.10.29.)
,Nielsen (2018b), „Ismét feltörekvőben a sajátmárkás termékek piaca”, Sajtószoba, 2018. március 13. https://www.nielsen.com/hu/hu/ press-room/2018/the-emerging-brand-of-selfbranded-products.html (letöltés: 2019.10.29.)

Olbrich, R., Hundt, M., Jansen, H. C. (2016), "Effects of pricing strategies and product quality on private label and national brand performance", Journal of Retailing and Consumer Services, 34 January, 294-301 DOI: 10.1016/j. jretconser.2016.01.012

Olson, E. L. (2012), ”Outing the supplier: Implications for manufacturers and retailers", Journal of Product \& Brand Management, 21 1, 47-52 DOI: $10.1108 / 106104212$

Pepe, M. S., Abratt, R., Dion, P. (2011), "The impact of private label brands on customer loyalty and product category profitability", Journal of Product \& Brand Management, 20 1, 27-36 DOI: $10.1108 / 10610421111107996$

Quelch, J. A., Harding, D. (1996), ”Brands versus private labels: Fighting to win", Harvard Business Review, 74 1, 99-109

Richardson, P. S., Jain, A. K., Dick, A. (1996), "Household store brand proneness: A framework", Journal of Retailing, 72 2, 159-85

Sayman, S., Hoch, J., Raju, S. (2002), Positioning of Store Brands. College of Administrative Sciences, Koç University, Rumeli Feneri Yolu, Sariyer, Istanbul 80910, Turkey

Sethuraman, R., Cole, C. (1997): Why do consumers pay more for national brands than for store brands? Report, Cambridge: Marketing Science Institute, December, 97-126

Wijmans, J. (2010): Power shift by private label? How does the introduction of private labels affect the bargaining power between retailers and national brand manufacturers and consequently influence a retailers assortment decisions? Pre-Master Marketing Management, University of Tilburg, http://arno.uvt.nl/show. cgi?fid=120654 
Dudás Gyula, tudományos főmunkatárs dudas.gyula@aki.naik.hu

Kürthy Gyöngyi, tudományos fömunkatárs kurthy.gyongyi@aki.naik.hu

Darvasné Ördög Edit, ügyvivő szakértő

Székelyhidi Katalin, tudományos segédmunkatárs

Radóczné Kocsis Teréz, ügyvivő szakértő

Takács Eszter, ügyvivő szakértő NAIK - Agrárgazdasági Kutatóintézet

Vajda Ágnes, PhD hallgató Állatorvostudományi Egyetem

\section{The expansion of private label foods - opportunity or threat for Hungarian food processors?}

\section{THE AIMS OF THE PAPER}

The market share of private label products is remarkable among food products in Europe and in Hungary as well. Private label products are also of major importance for retail chains, as --they make a significant contribution to consumers' loyalty to a given chain. Facing concentrated retail market, most suppliers have weak bargaining power also regarding the private label products. For this reason, our research was aimed to explore the experiences of Hungarian food processors regarding private label products, including reasons and motivations behind participating in their production.

\section{METHODOLOGY}

Besides the review of relevant literature, our research was based on a questionnaire survey conducted in 2018. The questionnaire was sent to about four thousand food processing companies. Responses were received from 157 companies, of which 68 produced private label food products for retail chains.

\section{MOST IMPORTANT RESULTS}

Private label products are direct competitors of manufacturer brands and are therefore an indispensable factor in the Hungarian food supply chain as well. The Hungarian food processors most often mentioned capacity utilization, increase of market share, constant high-volume production and predictable turnover as advantages of private label production. The most common disadvantages were low profitability, exposure to trade and product substitutability. Among those companies which did not participate in private label food production, the reason for it was not only the lack of sufficient production capacity but also the lack of intention Besides these, the protection of their own brand was an important factor.

\section{RECOMMENDATIONS}

The impact of private label production on the manufacturing industry cannot be clearly assessed as either a positive or a negative phenomenon. It depends on the particular situation and strategy of the given company, what advantages it can take and what disadvantages it can endure in exchange. Companies are typically conscious about the extent - a certain proportion of their turnover - to which they can commit themselves to the production of private label products. Therefore, the opportunities for external intervention are limited, although supporting an ethical relationship between suppliers and retailers seems to work in most cases.

Keywords: private label product, food industry, retail chain, bargaining power, motivation 